\title{
Memahami dan Mencegah Perilaku Plagiarisme dalam Menulis Karya Ilmiah
}

\section{Understanding and Avoiding Plagiarism Behavior in Scientific Writing}

\author{
Muhammad Abdan Shadiqi ${ }^{1}$ \\ Program Studi Psikologi, Fakultas Kedokteran Universitas Lambung Mangkurat; \\ Fakultas Psikologi Universitas Indonesia
}

\begin{abstract}
Plagiarism is a misconduct act and a scourge for science. Plagiarism perpetrators steal other author's work without citing the original references. Psychology is one of the most vulnerable sciences with plagiarism and must give more attention to this issue. Several types of plagiarism can be distinguished to the plagiarism motivation (intentional, unintentional, and inadvertent), how to do plagiarism (patchwriting, inappropriate paraphrasing, and summaries) and self-plagiarism (text recycling, redundant or duplicate publication, salami-slicing or data fragmentation). There are several reasons to do plagiarism, such as ease to get information via the internet, pressure on academic tasks, bad writing skill, hurry to write under pressure, lack of understanding how to rewrite the original reference, a misconception to understanding self-plagiarism, and habitual plagiarists. This article also presents steps to avoid plagiarism, such as avoiding "intellectual theft", doing good writing (citation and paraphrasing), and testing the similarity test (plagiarism detection service).
\end{abstract}

Keywords: academic writing; plagiarism; self-plagiarism; publication ethics

Abstrak. Plagiarisme adalah tindakan pelanggaran dan momok bagi ilmu pengetahuan. Pelaku plagiarisme mencuri karya penulis lain tanpa mengutip referensi asli. Psikologi adalah salah satu ilmu yang paling rentan dengan plagiarisme dan harus lebih memperhatikan masalah ini. Beberapa jenis plagiarisme dapat dibedakan dengan motivasi plagiarisme (disengaja, tidak disengaja, dan tidak disengaja), bagaimana melakukan plagiarisme (penulisan tulisan tangan, parafrase yang tidak sesuai, dan ringkasan) dan plagiarisme sendiri (daur ulang teks, publikasi yang berlebihan atau duplikat, salami-slicing atau fragmentasi data). Ada beberapa alasan untuk melakukan plagiarisme, seperti kemudahan mendapatkan informasi melalui internet, tekanan pada tugas akademis, keterampilan menulis yang buruk, terburu-buru untuk menulis di bawah tekanan, kurangnya pemahaman bagaimana menulis ulang referensi asli, kesalahpahaman untuk memahami plagiarisme diri, dan penjiplak kebiasaan. Artikel ini juga menyajikan langkah-langkah untuk menghindari plagiarisme, seperti menghindari "pencurian intelektual", melakukan penulisan yang baik (kutipan dan parafrase), dan menguji uji kesamaan (layanan deteksi plagiarisme).

Kata kunci: penulisan akademik; plagiat; plagiarisme diri; etika publikasi

\footnotetext{
${ }^{1}$ Korespondensi mengenai artikel ini dapat melalui: m.abdan_shadiqi@yahoo.co.id
} 


\section{Pengantar}

"...that your word is your bond and you do what you say and keep your promise; that you treat people with dignity and respect." Michelle Obama, 25 Agustus 2008 (Brown et al., 2008, para. 15).

"...that your word is your bond and you do what you say and keep your promise; that you treat people with respect." - Melania Trump, 18 Juli 2016 (Drabold, 2016, para. 8).

Dua kutipan pengantar di atas merupakan bukti kontroversi pidato Melania Trump yang disampaikan pada 18 Juli 2016 di Konvensi Nasional Partai Republik Amerika Serikat. Beberapa bagian pidato Melania Trump dinilai memiliki kesamaan dengan isi pidato Michelle Obama yang disampaikan pada Konvensi Nasional Partai Demokrat tahun 2008 (Turnitin.com, 2016a). Turnitin, sebagai salah satu layanan online untuk mendeteksi plagiarisme mengategorikan dua jenis plagiarisme yang terindikasi di pidato Melania Trump, yaitu "clone" atau menyalin kata demi kata dan "find-replace" atau mengubah beberapa kata tetapi memiliki makna kalimat yang sama Turnitin.com (2016a).

Di dunia akademik, isu plagiarisme bukanlah hal yang baru. Plagiarisme telah menjadi ancaman bagi integritas ilmu pengetahuan (Abad \& García, 2018). Awal tahun 2018, Ombudsman yang merupakan lembaga pengawas pelayanan publik melaporkan salah seorang petinggi perguruan tinggi yang diduga telah melakukan plagiarisme di tiga karya ilmiahnya (Khafifah \& Fatwalloh, 2018). Ombudsman menggunakan aplikasi Turnitin dan menemukan $72 \%$ kesamaan di antara beberapa karya ilmiah tersebut (Aliakbar, 2018). Padahal jauh sebelum laporan ini dibuat, pada 22 Juli 2017, Kementerian
Riset, Teknologi, dan Pendidikan Tinggi (Kemenristekdikti) telah memberikan klarifikasi mengenai dugaan Plagiarisme tersebut. Kemenristekdikti menyatakan bahwa meskipun terdapat beberapa kesamaan substantif pada bagian abstrak, pendahuluan, dan kesimpulan, tetapi artikel-artikel tidak terindikasi plagiarisme (Sumber Daya Iptek Dikti, 2017). Apakah mungkin pemahaman mengenai plagiarisme antara Ombudsman dan Kemenristekdikti berbeda?

Pada ranah ilmiah, naskah yang terbukti plagiarisme dapat berujung pada penarikan atau pembatalan publikasi, bahkan hingga tuntutan hukum (Jirge, 2017). Kontroversi dan perdebatan mengenai kasus plagiarisme hendaknya disikapi secara positif bagi para ilmuwan dan penulis Indonesia. Kasus-kasus yang terjadi dapat menjadi pelajaran dan membangun upaya pencegahan plagiarisme. Tidak banyak akademisi yang memahami batasan-batasan plagiarisme, hal ini terungkap saat pengalaman penulis memberikan materi plagiarisme di beberapa workshop penulisan karya ilmiah. Ini artinya ada kemungkinan plagiarisme dapat disebabkan oleh ketidaktahuan atau tanpa disengaja (accidental/unintentional plagiarism) daripada yang disengaja (deliberatelintentional plagiarism) (Marshall \& Rowland, 1998). Dapat pula terjadi karena lengah (tidak hati-hati), mengabaikan sumber pemikiran, dan tidak melakukan pengutipan secara baik (inadvertent plagiarism) (Barnett \& Campbell, 2012). Secara khusus, pada tulisan ini akan menguraikan macammacam plagiarisme yang lainnya, sebab terjadinya plagiarisme, dan menjelaskan upaya yang dapat dilakukan untuk mencegah terjadinya plagiarisme pada penulisan artikel ilmiah. 


\section{Pembahasan}

Plagiarisme oleh (The Office of Research Integrity, 1994) didefinisikan sebagai "to include both the theft or misappropriation of intellectual property and the substantial unattributed textual copying of another's work (para. 2)". Produk intelektual yang berisikan ide, data, dan tulisan merupakan bentuk hasil karya yang sering menjadi bahan plagiarisme (Cooper, 2016a). Plagiarisme sederhananya adalah melakukan copy dan paste dari produk intelektual orang lain yang disalahgunakan tanpa menyebutkan nama penulis, penemu, dan penggagas orisinal. Plagiarisme dapat terjadi secara disengaja maupun tidak disengaja, kedua alasan motivasional ini tetap dianggap sebagai plagiarisme jika pada dua karya ilmiah terdapat kesamaan tanpa melakukan sitasi dan perubahan teks asli menggunakan kata-kata sendiri.

Sekarang adalah era "paperless", ditandai dengan proses penyebaran hasilhasil penelitian melalui internet secara terbuka atau open access menggunakan tulisan digital atau tanpa harus melalui media yang dicetak pada kertas buku (Bosc \& Harnad, 2005). Era paperless dan internet dapat berdampak dalam menumbuhkan perilaku plagiarisme karena orang mudah mengakses karya orang lain (Debnath, 2016). Cara melakukan plagiarisme berubah dari era teks tinta melalui buku cetak ke era teks digital melalui internet (Sutherland-Smith, 2009). Ini artinya, jika dulu sebelum ada internet dan komputer orang akan sulit mendeteksi plagiarisme, sekarang dengan bantuan layanan daring akan lebih mudah mendeteksi indikasi plagiarisme.

\section{Tipe Plagiarisme: Motivasi Melakukan}

Tipe pertama yang dibahas adalah plagiarisme yang dibedakan berdasarkan motivasi melakukannya. Tiga jenis plagiarisme dari kategori ini adalah intentional, unintentional, dan inadvertent. Pada dasarnya ketiga jenis plagiarisme ini memiliki benang merah berupa kesengajaan, ketidaksengajaan, dan kelalaian. Cooper (2016b) menjelaskan bahwa plagiarisme tidak dapat dipandang dari motivasinya, plagiarisme tetaplah plagiarisme.

Intentional plagiarism terjadi ketika penulis secara sengaja melakukan aksi plagiarisme (Barnett \& Campbell, 2012), disebut pula dengan istilah deliberate plagiarism (Marshall \& Rowland, 1998). Kata atau ide dicatut sebagai tulisan orisinal, padahal produk intelektual tersebut berasal dari orang lain. Plagiarisme ini bentuk yang terberat, karena pelaku melakukannya secara sadar, bahkan merencanakan untuk menipu orang lain (Park, 2003). Ada kemungkinan jenis plagiarisme ini menyatu dengan jenis plagiarisme lain, misalnya ada penulis yang sengaja melakukan plagiarisme dengan berusaha mempublikasikan karya ilmiah yang sama di dua penerbit yang berbeda (self-plagiarism).

Unintentional plagiarism adalah bentuk yang berlawanan dengan jenis yang pertama, ditandai dengan ketidaksengajaan. Barnett dan Campbell (2012) memaparkan bahwa penulis mendengar atau membaca kata, frase, atau ide orang lain dan kemudian melupakan sumbernya. Pelaku berpikir bahwa apa yang ia tulis adalah ide orisinalnya. Ketidaksengajaan juga bisa bersumber dari ketidaktahuan, karena belum mengetahui secara jelas apa batasan yang disebut plagiarisme dan bukan plagiarisme. Park (2003) menjelaskan bahwa kemungkinan pelaku melakukan jenis unintentional plagiarism karena tidak memahami aturan dasar merujuk materi akademik, mengutip, menuliskan ide, hingga 
menyusun daftar pustaka. Elander, Pittam, Lusher, Fox, dan Payne (2010) menemukan intervensi dengan memberikan umpan balik secara langsung melalui kelompok yang terfokus antar-mahasiswa dapat menurunkan plagiarisme jenis ini, caranya adalah meningkatkan pemahaman tentang identitas kepenulisan.

Inadvertent plagiarism adalah bentuk terakhir dari tipe motivasi plagiarisme. Jenis ini mirip dengan unitentional plagiarism, perbedaannya adalah pelaku lalai atau lengah mengabaikan sumber pemikiran atau tidak mencatat kutipan (Barnett \& Campbell, 2012). Salah satu jalan untuk memastikan bahwa pelaku melakukan jenis intentional, unintentional, atau inadvertent dengan menanyakan atau menginvestigasi langsung. Selain itu, analisis tingkat plagiarisme menggunakan alat atau software tetap dibutuhkan untuk menambah bukti mengenai kasus plagiarisme.

\section{Tipe Plagiarisme: Ditinjau dari Cara Melakukan}

Tipe plagiarisme dapat dijelaskan melalui bagaimana cara melakukannya. Terdapat tiga jenis plagiarisme, yaitu pathwriting, inappropriate praraphasing, dan summaries. Titik poin dari ketiga jenis plagiarisme ini adalah apakah penulis menyalin, mengubah, dan menyingkat tulisan orang lain dengan menggunakan kaidah pengutipan dan parafrase secara baik.

Patchwriting adalah menyalin teks yang pernah ada sebelumnya tanpa menyebutkan sumber orisinal (Roig, 2003). Tindakan ini menurut Roig termasuk menggunakan sinonim dan memperpendek/memperpanjang frase. Contoh patchwriting adalah ketika ada mahasiswa yang menyelesaikan tugas makalah dengan mengambil isi makalah milik orang lain yang tersebar di internet dan diklaim sebagai tulisan sendiri tanpa ada informasi sumber orisinal. Hendaknya kita harus berhati-hati untuk mengutip tulisan yang tersebar di internet, karena tidak ada batasan dan tidak mudah menyaring informasi yang akurat dan terpercaya. Terlebih lagi, misalnya pada blogspotblogspot, agak sulit untuk meyakinkan bahwa suatu tulisan yang kita kutip adalah hasil karya orisinal penulis blogspot, bisa saja ternyata penulis blogspot tersebut juga telah melakukan patchwriting terhadap tulisan orang lain sebelumnya.

Inappropriate praraphrasing, mirip patchwriting, tetapi sumber orisinal tetap disebutkan, hanya saja sedikit dilakukan perubahan tanpa diberi tanda petik yang mengindikasikan bentuk kutipan langsung (Cooper, 2016a). Kutipan sendiri sederhananya diartikan sebagai bentuk tulisan (kalimat atau paragraf) yang bukan hasil buah pikiran kita sendiri, tetapi berasal dari orang lain. Pada penulisan karya ilmiah, lazim untuk melakukan kutipan langsung dan tidak langsung. Perbedaan dari dua jenis kutipan ini terletak pada apakah kita melakukan perubahan (kutipan tidak langsung) atau sama persis (kutipan langsung) dengan tulisan orisinal dan tetap menyebutkan sumber orisinalnya.

Inappropriate praraphrasing terjadi ketika penulis melakukan kutipan tidak langsung, alih-alih menggunakan kalimat yang dibuat sendiri dengan ide pokok yang sama dengan sumber aslinya (parafrase), tetapi pelaku plagiarisme jenis ini hanya mengganti, menambah, atau mengurangi beberapa kata dalam 1 kalimat/paragraf dengan tetap mencantumkan sumber sitasi. Misalnya ketika menggunakan contoh kasus Melania Trump, bayangkan Melania melakukan kutipan tidak langsung dengan tetap menyebutkan sumber orisinal pada 
pidatonya dan menuliskan: that you treat people with respect Obama (2008), berasal dari sumber orisinal berikut: that you treat people with dignity and respect Obama (2008). Ini artinya Melania Trump hanya menghapus satu kata dignity, maka ia dapat terindikasi telah melakukan inappropriate prapraphrasing.

Summaries adalah menyingkat tulisan orang lain tanpa menyebut sumber atau tidak menggunakan pengutipan secara baik (Cooper, 2016a). Penulis harus dibekali kemampuan untuk dapat menyampaikan pemikiran penulis orisinal dengan kata-kata yang berbeda tanpa menghilangkan maknanya. Cooper menjelaskan bahwa permasalahan plagiarisme akan menjadi isu krusial bagi penulis yang tidak menggunakan bahasa Inggris sebagai bahasa ibu mereka, misalnya penulis Indonesia yang lebih terbiasa menggunakan bahasa Indonesia. Akan sangat mungkin para penulis Indonesia mengalami kesulitan untuk mengutip atau meringkas tulisan berbahasa Inggris. Ketika diminta menulis dalam bahasa Indonesia juga tidak bisa dipungkiri bahwa mungkin ada sebagian dari penulis Indonesia yang hanya melakukan translasi tulisan orang lain dari bahasa orisinal ke bahasa Indonesia, tanpa melakukan kutipan atau parafrase secara baik.

\section{Tipe Plagiarisme: Self-Plagiarisme}

Jenis plagiarisme ini yang harus diperhatikan secara khusus oleh para akademisi. Tipe ini adalah bentuk plagiarisme yang dilakukan terhadap hasil karya sendiri. Para penulis harus memahami secara baik batasan apa yang disebut dengan selfplagiarisme dan yang bukan termasuk jenis ini. Terdapat tiga jenis self-plagiarisme, yaitu text recycling, redundant and duplicate publication, dan salami-slicing atau data fragmentation.
Text recycling terjadi ketika peneliti bekerja secara sistematik pada suatu topik menggunakan tulisan dia sebelumnya atau tulisan yang belum terbit untuk tujuan yang baru (Burdine, de Castro Maymone, \& Vashi, 2018; Cooper, 2016a; Mohapatra \& Samal, 2014). Permasalahan text recycling ini kerap terjadi di ekonomi dan psikologi (Horbach \& Halffman, 2019). Text recycling tidak dianggap plagiarisme jika suatu naskah sebelumnya ditulis untuk dokumen 'internal' yang tidak terpublikasi atau tanpa copyright dan lisensi penerbit. Misalnya untuk tugas akhir (skripsi, tesis, disertasi) yang belum dipublikasikan, proposal hibah untuk pengajuan pendanaan ke sponsor, dan makalah singkat yang ditulis untuk kebutuhan sendiri saat akan mempresentasikan suatu hasil penelitian pada konferensi (Cooper, 2016a; Roig, 2003). Makalah singkat untuk kebutuhan presentasi ini berbeda dengan artikel prosiding, karena kadang ada peneliti yang menulis makalah singkat hanya untuk bahan bacaan saat akan presentasi. Jika seorang penulis yang mengikuti konferensi mengirimkan naskahnya untuk dipublikasikan ke prosiding konferensi, maka naskah itu tidak boleh dipublikasikan kembali menjadi artikel jurnal. Karena suatu prosiding konferensi biasanya telah memiliki copyright dari penyelenggara konferensi atau penerbit. Di jenis karya ilmiah lain, terkadang ada tugas akhir (seperti disertasi) yang dibukukan oleh penulis dan telah berISBN (International Standard Book Number) sehingga tidak boleh dipublikasikan ke bentuk karya ilmiah lain seperti artikel jurnal ilmiah atau artikel prosiding.

Konsep text recycling ini harusnya dipahami dengan baik oleh penulis, reviewer, editor, dosen, dan mahasiswa. Terkadang mungkin kita dihadapkan 
dengan usaha untuk mereplikasi studi kita yang terdahulu untuk mengembangkan suatu temuan yang baru (Shadiqi, Muluk, \& Milla, 2018). Pada kasus ini, yang perlu dipahami oleh semua akademisi atau penggiat jurnal ilmiah adalah suatu tulisan dapat memiliki pendahuluan dan metode penelitian atau bagian lainnya yang mirip dengan tulisan lain yang ditulis oleh orang yang sama karena tujuan untuk studi replikasi. Meskipun tidak ada standar batas berapa persen boleh melakukan text recycling, nilai yang dapat diterima sekitar $10 \%$ untuk tiap bagian pendahuluan dan metode penelitian, dan 5\% untuk bagian lainnya (Moskovitz, 2017). Ini artinya selfplagiarisme tidak dapat dikategorikan kecurangan akademik jika tujuannya adalah untuk meletakkan dasar pijakan untuk karya baru, konsep baru, dan pembaca yang berbeda (Wibowo, 2012).

Redundant and duplicate publication terjadi saat penulis mempublikasikan artikel atau tulisan yang sama di tempat yang berbeda tanpa memberitahu pembaca atau penerbit (Cooper, 2016a). Salah satu kasus untuk memahami jenis selfplagiarisme ini adalah penarikan naskah yang dilakukan oleh Jurnal Ecopsy karena terindikasi dipublikasikan di tiga jurnal lainnya (Rachmah, 2018). Jenis selfplagiarisme ini dapat terjadi karena ketidaktahuan penulis mengenai aturan etika publikasi atau memang sengaja dilakukan untuk tujuan tertentu. Penulis tidak boleh "menebar jaring" dengan menyebarkan naskah ilmiahnya ke beberapa jurnal hanya untuk tujuan mendapatkan publikasi tercepat karena tuntutan kewajiban pribadi, seperti proses kelulusan studi. Larangan "menebar jaring" semacam ini harusnya menjadi pengetahuan umum dan aturan yang dijelaskan oleh para editor jurnal ilmiah melalui aturan publikasi (Committee on Publica- tion Ethics, n.d.). Redundant publication juga dapat terjadi karena tidak terjalin komunikasi yang baik antara penulis pertama dan penulis lainnya pada satu artikel ilmiah. Penulis kedua tanpa memberitahu penulis pertama mengirimkan naskah mereka ke suatu jurnal, sementara penulis pertama juga melakukan hal yang sama pada jurnal yang berbeda di waktu yang bersamaan atau berbeda.

Salami-slicing atau data fragmentation adalah memecah studi ke beberapa publikasi demi menghindari publikasi satu studi besar (Cooper, 2016a; Elston, in press; Mohapatra \& Samal, 2014). Tidak semua publikasi termasuk jenis ini, contoh yang diperbolehkan adalah ketika ada suatu disertasi dipecah menjadi 1 (satu) naskah literatur review dan 2 (dua) naskah yang lain dengan dua kelompok sampel yang berbeda. Contoh lain yang diperbolehkan adalah ketika peneliti mempunyai 1000 sampel studi survei, 500 data ditulis untuk 1 naskah alat ukur variabel $X, 500$ data yang lain ditulis untuk naskah korelasional variabel $\mathrm{X}$ dan $\mathrm{Y}$. Dengan catatan, kedua naskah benarbenar ditulis berbeda untuk menjelaskan dua persoalan yang berbeda, yaitu validasi alat ukur dan hubungan antar variabel. Sementara indikasi plagiarisme dapat terjadi ketika pada suatu studi dipecah menjadi 1 (satu) naskah berisikan studi komparasi dua kelompok dan 1 (satu) naskah yang lain melaporkan salah satu kelompok saja (variabel sama, analisis hasil berbeda). Hal ini didukung dengan adanya bukti bahwa kedua naskah tersebut memiliki tingkat kesamaan yang tinggi melalui uji plagiarisme. Ada kecenderungan saat ini para peneliti berusaha mempublikasikan naskah sebanyak-banyaknya meskipun dengan data yang sama. Secara etis hal demikian 
dapat diatasi dengan cara yang tepat, namun akan muncul pertanyaan mengapa tidak mempublikasikan satu naskah dengan hasil yang lengkap untuk menjelaskan satu persoalan yang sama?

Berbeda hal jika kita berbicara tentang artikel review, kita mungkin pernah menemukan artikel literatur review dengan topik yang sama ditulis orang yang sama dipublikasikan pada jurnal yang berbeda dan terdapat beberapa kesamaan ide topik tulisan. Hal seperti ini boleh dilakukan sejauh artikel-artikel tersebut ditujukan untuk pembaca yang berbeda (Elston, in press), misalnya ketika topik A dibahas pada suatu artikel menggunakan sudut pandang psikologi dan artikel yang lain ditulis dengan pendekatan sosiologi oleh satu orang penulis yang sama. Namun, perlu ditekankan bahwa dua naskah dengan konsep yang sama harus melewati uji plagiarisme dan memiliki batas indikasi kesamaan yang masih bisa ditoleransi. Sementara itu, pada artikel studi empiris, penulis dapat menghindari self-plagiarisme dengan cara melakukan suatu penelitian yang menguji beberapa variabel dengan jumlah sampel yang besar dan memecahnya menjadi beberapa artikel. Meskipun berasal dari 1 pengambilan data yang sama, akan terdapat beberapa naskah dengan pertanyaan penelitian yang berbeda, variabel yang berbeda, dan sampel yang berbeda.

Tipe Plagiarisme: 10 Spektrum Plagiarisme dari Turnitin

Turnitin.com (2016b) mengategorikan 10 jenis plagiarisme yang berasal dari survei hampir 900 instruktur pendidikan sekolah menengah dan tinggi seluruh dunia. Adapun kesepuluh jenis plagiarisme ini adalah (1) Clone, mengkloning atau menulis sama persis tulisan orang lain kata demi kata. (2) $C T R L+C$, menulis bagian teks dari satu sumber tanpa ada perubahan yang signifikan. (3) FindReplace, mengganti kata dan frase kunci dari sumber lain dengan tetap mempertahankan konten utama. (4) Remix, melakukan parafrase dari berbagai sumber dan ditulis menjadi satu (tanpa sumber). (5) Recycle, meminjam tulisan orang lain terdahulu tanpa mencantumkan sumber. (6) Hybrid, mengombinasikan tulisan orang lain dengan menyisipkan satu tulisan lainnya dan tetap mencantumkan salah satu sumber tanpa melakukan prosedur pengutipan. (7) Mashup, mencampurkan berbagai tulisan/material dari berbagai sumber. (8) 404 Error, menggunakan tulisan orang lain tetapi diberi sumber yang tidak akurat atau bahkan menuliskan sumber yang mengada-ada. (9) Aggregator, melakukan pengutipan secara tepat (mengubah tulisan orang lain) tetapi sumber hampir tidak ada yang asli (mengada-ada). (10) Re-Tweet, melakukan pengutipan secara tepat, tetapi terlalu mirip dengan kata-kata atau struktur sumber asli. Untuk lebih jelas contohcontoh 10 jenis plagiarisme ini dapat dilihat langsung pada situs Turnitin di sumber yang tercantum di daftar pustaka tulisan ini.

\section{Mengapa Melakukan Plagiarisme?}

Debnath (2016) merangkum setidaknya ada 8 alasan mengapa plagiarisme dilakukan, yaitu (1) Informasi yang tersedia dengan mudah, terlebih lagi dengan adanya internet. (2) tekanan publikasi dari tuntutan akademik, baik bagi dosen atau mahasiswa yang sedang mengejar target akademik. (3) Kurang percaya diri dan kurang terampil menulis, sering kali terjadi pada penulis pemula. (4) Menulis artikel terburu-buru dan di bawah tekanan. (5) Kurangnya pemahaman dan kesadaran mengenai plagiarisme. 
Kurangnya kesadaran bahwa sekalipun orang lain memberikan teks orisinal tetap tidak diperkenankan melakukan usaha penyalinan tanpa menyebutkan sumber orisinal. (7) Beberapa penulis meyakini bahwa tidak masalah menulis ulang konsep/data/teks yang mereka miliki (selfplagiarisme) dan publikasikan sebelumnya tanpa melakukan penulisan sumber (self-citation), asalkan tidak menyalin karya orang lain. (8) Telah terbiasa melakukan plagiarisme, dipermudah dengan adanya komputer dan internet, serta pernah melakukan plagiarisme di masa lalu atau belum pernah tertangkap hingga sekarang. Sebuah penelitian kualitatif turut mendukung 2 dari 8 alasan yang dijelaskan oleh Debnath (2016), penelitian ini menemukan bahwa dua faktor yang menyebabkan mahasiswa di Fakultas Tarbiyah IAIN Imam Bonjol Padang melakukan plagiarisme, yaitu karena kemudahan akses informasi dan tuntutan tugas kuliah dengan waktu yang terbatas (Zalnur, 2012).

Plagiarisme tidak hanya diakibatkan oleh perilaku dari pelaku. Kurangnya kontrol yang ketat terhadap penulisan karya ilmiah oleh otoritas pendidikan juga memungkinkan suburnya plagiarisme di Indonesia. Pada institusi pendidikan, dosen dan mahasiswa dapat menjadi pela$\mathrm{ku}$ plagiarisme, para pemimpin institusi pendidikan harus membuat aturan tegas untuk mengurangi kecenderungan melakukan plagiarisme. Plagiarisme dapat pula terjadi dikarenakan pengelolaan jurnal yang buruk. Editor dan reviewer sebagai pihak otoritas jurnal hendaknya secara konsisten menerapkan standar yang ketat pada naskah, dimulai dengan melakukan uji plagiarisme, melakukan pengecekan awal naskah yang masuk, melakukan proses review (double blind review: penulis dan review sama-sama tidak saling tahu identitas masing-masing, single blind review: penulis tidak tahu siapa reviewer-nya, atau open review: kedua pihak saling tahu), dan mengomunikasikan secara aktif proses pengelolaan naskah kepada penulis.

\section{Menghindari Plagiarisme}

Terdapat 3 langkah yang dapat dilakukan untuk menghindari plagiarisme Cooper (2016b): (1) Menghindari pencurian ide "intellectual theft" dengan menyitasi sumber orisinal, sumber yang paling representatif, atau sumber paling terbaru. (2) Melakukan pengutipan dan parafrase. (3) Menggunakan layanan uji plagiarisme.

Penting untuk memperhatikan sumber referensi yang digunakan untuk menulis artikel ilmiah. Jika mengutip acuan sekunder (dari sumber kedua), baca acuan orisinal (dari sumber pertama). Hindari penggunaan acuan sekunder sebagai referensi (biasanya menggunakan ditulis dengan: "(penulis orisinal dalam penulis sekunder, tahun)", karena kita tidak dapat memastikan bahwa acuan sekunder tersebut telah melakukan pengutipan atau parafrase secara baik dan telah terbebas dari plagiarisme. Lebih baik membaca acuan orisinal untuk memastikan apa yang ditulis oleh orang lain memang sesuai dengan ide pokok yang tertulis di acuan orisinal. Selain itu, penting untuk menghindari referensi yang berasal dari sumber yang tidak jelas, utamakan referensi adalah bentuk karya ilmiah dan paling representatif. Halaman website, berita online, tulisan blogspot, dan jenis tulisan online lainnya perlu dikutip secara hati-hati, pastikan bahwa tulisan di sumber ini ditulis sendiri oleh pemilik website, reporter/penulis berita, atau penulis blogspot. Jika mengutip acuan orisinal juga harus memperhatikan copyright, seperti penggunaan tabel dan 
gambar dari artikel ilmiah lain untuk ditulis kembali ke tulisan kita. Beberapa tabel dan gambar yang memiliki copyright harus ditulis dengan menyebutkan sumber referensi di keterangan bawah tabel dan gambar, bahkan harus mendapat izin dari penulis atau penerbitnya.

Langkah berikutnya untuk menghindari plagiarisme adalah ketika melakukan parafrase dan meringkas selalu sebutkan sumber asli atau menggunakan kutipan langsung ketika menggunakan frase orisinal (Cooper, 2016a). American Psychological Association (2013) telah membuat aturan khusus untuk penulisan kutipan. APA menjelaskan bahwa jika kutipan langsung memiliki kurang dari 40 kata maka ditulis di dalam paragraf dengan menggunakan tanda petik (“...") dan diakhiri dengan sitasi sumber orisinal berupa nama belakang penulis, tahun, dan nomor halaman/paragraf yang memuat tulisan orisinal. Namun jika lebih dari 40 kata, maka dibuat teks blok berupa tulisan yang terpisah dan menjorok lebih dalam dari paragraf awal, tanpa tanda petik, dan tetap diakhiri dengan sumber sitasi serta nomor halaman tulisan orisinal. Untuk lebih jelas dapat dilihat pada buku Publication manual of the American Psychological Association edisi ke-6.

Jika seorang penulis melakukan parafrase tulisan ia sendiri sebelumnya dengan mempertahankan makna orisinal dan tetap menyebutkan sumber tulisannya sendiri (self-citation), ini tepat dan etis dilakukan (Burdine et al., 2018). Namun, penulis harus memperhatikan aturan mengenai self-citation. Memang tidak ada kesepakatan sejauh mana self-citation boleh dilakukan (Pandita \& Singh, 2017). Beberapa alasan berikut memperbolehkan untuk self-citation (Pandita \& Singh, 2017): (1) Mengembangkan studi sebelumnya. (2) Mengisi gap (celah) penelitian terbaru dengan menggunakan temuan terdahulu. (3) Memperbaiki atau memasukkan perubahan yang diperlukan pada suatu temuan sebelumnya. (4) Spesialisasi yang hanya mengarah pada penulis tersebut, ia yang lebih banyak menguasai topik tersebut. Sementara yang kurang etis adalah (5) meningkatkan angka H-Index melalui jumlah sitasi yang banyak.

Langkah yang lain adalah melakukan uji plagiarisme untuk mengecek kualitas tulisan. Burdine et al. (2018) membuat daftar layanan uji plagiarisme secara daring yang berbayar seperti iThenticate, CrosCheck, Plagium, PlagScan, dan Turnitin. Sementara uji plagiarisme tanpa biaya atau gratis adalah HelioBLAST, Viper, Grammerly, dan Plagiarisma (Burdine et al., 2018). Jenis terakhir terdapat tambahan biaya jika ingin meningkatkan (upgrade) layanan. Terkadang melakukan pencarian di google atau google scholar juga dapat membantu mendeteksi plagiarisme (Debnath, 2016). Bagi pengelola jurnal, langkah yang paling awal dan sederhana adalah melakukan pencarian judul naskah di google dan memastikan bahwa naskah belum dipublikasikan di terbitan apapun.

Tiap institusi pendidikan dan jurnal ilmiah memiliki standar yang berbeda untuk uji plagiarisme, misalnya Pastor (2018) menggunakan Turnitin dengan standar kode warna biru (tanpa kesamaan atau $0 \%$ ), hijau (kesamaan dengan besar 24\%), kuning (antara 25 hingga 49\%), jingga (50-74\%) dan merah (lebih dari 75\%). Tiap institusi pendidikan hendaknya memiliki layanan uji plagiarisme yang dapat digunakan oleh sivitas akademik. Setidaknya dengan layanan ini, plagiarisme dapat dihalau meskipun hanya bersumber dari data online. Namun, kita harus tetap menyadari kelemahan uji plagiarisme online ini, yaitu tidak dapat 
mendeteksi naskah-naskah dicetak menggunakan kertas.

Terdapat beberapa bentuk tulisan yang tidak dikategorikan sebagai bentuk plagiarisme meskipun ditulis berulang kali. Pengetahuan umum bukan termasuk plagiarisme, misalnya notasi statistik (Cooper, 2016a). Notasi statistik ditulis secara standar dan akan sangat mungkin ditulis dengan cara yang sama oleh dua orang penulis yang berbeda. Berikutnya adalah judul, abstrak dan daftar pustaka juga bukan bentuk plagiarisme. Ada kalanya judul dan abstrak suatu studi dikirim untuk mengikuti konferensi, beberapa panitia penyelenggara konferensi biasanya membuat buku informasi yang memuat judul dan abstrak atau menempatkannya ke website konferensi. Begitu pula daftar pustaka tidak dapat dikategorikan sebagai plagiarisme, karena pasti akan ditulis sama dan terstandar. Judul, abstrak, dan referensi biasanya dalam pengujian plagiarisme tidak diikutkan.

Pencegahan plagiarisme menjadi tanggung jawab semua pihak. Bagi para pengelola jurnal sangat penting untuk menjelaskan kebijakan dan aturan mengenai plagiarisme di halaman jurnal online (Horbach \& Halffman, 2019). Selain itu, pastikan penulis dapat dengan mudah menjangkau informasi mengenai isu ini. Pengetahuan mengenai batasan plagiarisme harus dipahami dengan baik tidak hanya oleh editor, reviewer, dan penulis jurnal. Di institusi pendidikan, pencegahan plagiarisme dapat dilakukan dengan menumbuhkan integritas ilmiah, sosialisasi plagiarisme, membuat pedoman praktis, dan optimalisasi peran tim kaji etik (Wibowo, 2012). Ini artinya sivitas akademik (mahasiswa dan dosen) serta para pembuat kebijakan di institusi pendidikan juga memiliki peran penting untuk memerangi plagiarisme.

\section{Penutup}

Selain ancaman jurnal predator, plagiarisme merupakan salah satu momok bagi ilmu pengetahuan (Aba \& García, 2018). Psikologi adalah salah satu ilmu yang rentan mengalami plagiarisme (Horbach \& Halffman, 2019). Plagiarisme tidak hanya diartikan secara sederhana dengan menulis ulang karya diri sendiri atau orang lain tanpa menyebutkan sumber acuan, tetapi banyak tipe-tipe plagiarisme yang perlu dipahami secara mendalam. Plagiarisme tidak hanya menjadi tanggung jawab para peneliti dan penulis, tetapi juga menjadi perhatian penting bagi pengelola jurnal (editor dan reviewer), sivitas akademik (dosen dan mahasiswa), serta pemangku kebijakan di bidang pendidikan. Hal yang paling mendasar sebagai usaha pencegahan plagiarisme adalah memahami plagiarisme dimulai dari diri sendiri dan melakukan kaidah penulisan dengan baik (good writing). Kemudian dilanjutkan dengan membangun suasana akademik yang jujur dan integritas hingga menciptakan etika publikasi. Teknologi informasi seperti penggunaan uji plagiarisme juga turut menunjang pembatasan perilaku plagiarisme.

Pada dasarnya tulisan ini dapat menjadi awal untuk mengantarkan usaha pencegahan plagiarisme. Namun, tulisan ini memiliki keterbatasan dalam memaparkan hasil-hasil studi plagiarisme yang terjadi di Indonesia. Penulis menyarankan untuk dilakukan studi-studi untuk menjelaskan perilaku plagiarisme dengan menggunakan pendekatan psikologi. Setelah menemukan akar masalah yang terjadi di Indonesia, penelitian selanjutnya dapat merancang dan membuktikan intervensi 
yang cocok untuk mencegah dan mengurangi perilaku plagiarisme. Kemudian, penelitian yang berikutnya dapat menerapkan bentuk intervensi tersebut dengan program kebijakan yang diatur oleh otoritas pendidikan.

\section{Ucapan Terima Kasih}

Penulis mengucapkan terima kasih kepada Corina D. Riantoputra, Ketua Editor Makara Human Behavior Studies in Asia (Makara Hubs-Asia), Universitas Indonesia (UI) yang telah memberi kesempatan bagi penulis untuk membantu proses desk review naskah dan melakukan pengujian plagiarisme. Penulis banyak mendapatkan ide tulisan setelah mengetahui lebih jauh tentang proses pengujian plagiarisme. Artikel ini ditulis saat penulis menjadi mahasiswa doktoral di UI dan tergabung menjadi staf editorial Makara Hubs-Asia.

\section{Daftar Pustaka}

Abad-García, M. F. (2018). Plagiarism and predatory journals: A threat to scientific integrity. Anales de Pediatría (English Edition), 90(1), 57.e1-57.e8. doi: 10.1016/j.anpede.2018.11.006

Aliakbar, L. O. (2018, February 6). Tim tiga puluh Guru Besar UHO sebut plagiat Zamrun 72 persen terbukti. Sultrakini.Com. Diunduh dari https://sultrakini.com/berita/tim-tigapuluh-guru-besar-uho-sebut-plagiatzamrun-72-persen-terbukti

American Psychological Association. (2013). Publication manual of the American Psychological Association. Washington, DC: American Psychological Association.

Barnett, J. E., \& Campbell, L. F. (2012). Ethics issues in scholarship. In S. J. Knapp (Ed.), PA handbook of ethics in psychology: Vol. 2. Practice, teaching, and research (pp. 309-333). Washington, DC: American Psychological Association.

Bosc, H., \& Harnad, S. (2005). In a paperless world a new role for academic libraries: Providing open access. Learned Publishing, 18(2), 95-99. Retrieved from https://archivesic.ccsd.cnrs.fr/sic 0012 $\underline{0214}$

Brown, C., Dance, G., Ellis, J., Gerst, B., Jackson, T., Sharpe, M., \& Wheaton, S. (2008, August 25). Michelle Obama's remarks at the Democratic convention. The New York Times. Diunduh dari https://www.nytimes.com/elections/20 08/president/conventions/videos/trans cripts/20080825 OBAMA SPEECH.ht $\underline{\mathrm{ml}}$

Burdine, L. K., de Castro Maymone, M. B., \& Vashi, N. A. (2018). Text recycling: Self-plagiarism in scientific writing. International Journal of Women's Dermatology, 5(2), 134-136. doi: $\underline{10.1016 / j . i j w d .2018 .10 .002}$

Committee on Publication Ethics. (n.d.). Core practices. Diunduh dari https://publicationethics.org/corepractices

Cooper, H. (2016a). Ethical choices in research: Managing data, writing reports, and publishing results in the social sciences. Washington, DC: American Psychological Association.

Cooper, H. (2016b). Principles of good writing: Avoiding plagiarism. Retrieved January 27, 2019, from APA Style Blog website:

https://blog.apastyle.org/apastyle/2016 105/avoiding-plagiarism.html

Debnath, J. (2016). Plagiarism: A silent epidemic in scientific writing Reasons, recognition and remedies. 
Medical Journal Armed Forces India, 72(2), 164-167. doi: 10.1016/j.mjafi.2016.03.010

Drabold, W. (2016, July 19). Watch Melania Trump's speech at the Republican convention. TIME. Retrieved from https://time.com/4412008/republicanconvention-melania-trump-2/

Elander, J., Pittam, G., Lusher, J., Fox, P., \& Payne, N. (2010). Evaluation of an intervention to help students avoid unintentional plagiarism by improving their authorial identity, Assessment \& Evaluation in Higher Education, 35(2), 157-171. doi: $\underline{10.1080 / 02602930802687745}$

Elston, D. M. (in press). Duplicate publication. Journal of the American Academy of Dermatology. doi: 10.1016/j.jaad.2017.11.015

Horbach, S. P. J. M., \& Halffman, W. (2019). The extent and causes of academic text recycling or "selfplagiarism." Research Policy, 48(2), 492502. doi: 10.1016/j.respol.2017.09.004

Jirge, P. R. (2017). Preparing and publishing a scientific manuscript. Journal of Human Reproductive Science, 10(1), 3.

Khafifah, N., \& Fatwalloh, Y. (2018, January 29). Ombudsman: Rektor Universitas Halu Oleo terbukti lakukan plagiarisme. KumparanNEWS. Retrieved from https://kumparan.com/@kumparanne ws/ombusman-rektor-universitashalu-uleo-terbukti-lakukanplagiarisme

Marshall, L., \& Rowland, F. (1998). A guide to learning independently, 3rd Edition. Melbourne: Addison Wesley Longman.

Mohapatra, S., \& Samal, L. (2014). The ethics of self-plagiarism. Asian Journal of Psychiatry, 12(1), 147-147. doi: 10.1016/j.ajp.2014.10.005

Moskovitz, C. (2017). Text recycling in health sciences research literature: A rhetorical perspective. Research Integrity and Peer Review, 2(1), 1. doi: 10.1186/s41073-017-0025-Z

Pandita, R., \& Singh, S. (2017). Selfcitations, a trend prevalent across subject disciplines at the global level: an overview. Collection Building, 36(3), 115-126. doi: 10.1108/CB-03-2017-0008

Park, C. (2003). In other (people's) words: Plagiarism by university students-literature and lessons. Assessment and Evaluation in Higher Education, 28(5), 37-41. doi: $\underline{\text { 10.1080/02602930301677 }}$

Pastor, J. C. (2018). Plagiarism in publications. Archivos de La Sociedad Espanola de Oftalmologia, 93(12), 571572. doi: $\underline{10.1016 / j . o f t a l .2018 .08 .009}$

Rachmah, D. N. (2018). Pengumuman editor: Penarikan satu naskah pada Vol. 5 No. 1 April 2018. Jurnal Ecopsy, 5(2), 110. Diunduh dari https://ppjp.ulm.ac.id/journal/index.ph p/ecopsy/article/view/5411

Roig, M. (2003). Avoiding plagiarism, selfplagiarism, and other questionable writing practices. Retrieved from https://ori.hhs.gov/avoidingplagiarism-self-plagiarism-and-otherquestionable-writing-practices-guideethical-writing

Shadiqi, M. A., Muluk, H., \& Milla, M. N. (2018). Experiment replication: A proposed solution for developing psychological research in Indonesia. Anima Indonesian Psychological Journal, 33(4), 213-230. doi: 10.24123/aipj.v33i4.1795

Sumber Daya Iptek Dikti. (2017). Klarifikasi dugaan plagiasi rektor terpilih Universitas Halu Oleo. 
Diunduh

dari

http://sumberdaya.ristekdikti.go.id/in

dex.php/2017/07/22/klarifikasi-

dugaan-plagiasi-rektor-terpilih-

universitas-halu-oleo/ pada

30

December 2018,

Sutherland-Smith, W. (2009). Plagiarism, the Internet, and student learning: Improving academic integrity. New York: Routledge.

The Office of Research Integrity. (1994). ORI policy on plagiarism. ORI Newsletter, 3(1), 5-6. Retrieved from http://ori.hhs.gov/ori-policyplagiarism

Turnitin.com. (2016a). Melania Trump trumped by plagiarism? Understanding plagiarism to avoid controversy. Retrieved December 30,
2018, from Turnitin.com website: https://www.turnitin.com/blog/melani a-trump-trumped-by-plagiarism

Turnitin.com. (2016b). The plagiarism spectrum. Retrieved January 26, 2019, from

https://www.turnitin.com/static/plagia rism-spectrum/

Wibowo, A. (2012). Mencegah dan menanggulangi plagiarisme di dunia pendidikan. Jurnal Kesehatan Masyarakat Nasional, 6(5), 195-200. doi: $\underline{10.21109 / \text { kesmas.v6i5.84 }}$

Zalnur, M. (2012). Plagiarisme di kalangan mahasiswa dalam membuat tugastugas perkuliahan pada Fakultas Tarbiyah IAIN Imam Bonjol Padang. AL-Ta'Lim, 19(1), 55-66. doi: 10.15548/jt.v19i1.6 